\title{
Conversion of Rice Hull Ash into Soluble Sodium Silicate
}

\author{
Edson Luiz, Foletto*, Ederson Gratieri, Leonardo Hadlich de Oliveira, Sérgio Luiz Jahn \\ Department of Chemical Engineering, Federal University of Santa Maria, \\ 97105-900 Santa Maria - RS, Brazil
}

Received: April 5, 2006; Revised: June 26, 2006

\begin{abstract}
Sodium silicate is used as raw material for several purposes: silica gel production, preparation of catalysts, inks, load for medicines, concrete hardening accelerator, component of detergents and soaps, refractory constituent and deflocculant in clay slurries. In this work sodium silicate was produced by reacting rice hull ash (RHA) and aqueous sodium hydroxide, in open and closed reaction systems. The studied process variables were time, temperature of reaction and composition of the reaction mixture (expressed in terms of molar ratios $\mathrm{NaOH} / \mathrm{SiO}_{2}$ and $\mathrm{H}_{2} \mathrm{O} / \mathrm{SiO}_{2}$ ). About $90 \%$ silica conversion contained in the RHA into sodium silicate was achieved in closed system at $200{ }^{\circ} \mathrm{C}$. The results showed that sodium silicate production from RHA can generate aggregate value to this residue.
\end{abstract}

Keywords: sodium silicate, silicate synthesis, rice hull ash

\section{Introduction}

The manufacture process of sodium silicate generally comprises the following stages ${ }^{1}$ : a) calcination of a mixture of sodium carbonate $\left(\mathrm{Na}_{2} \mathrm{CO}_{3}\right)$ and natural quartz sand $\left(\mathrm{SiO}_{2}\right)$ in appropriate furnaces at 1400-1500 ${ }^{\circ} \mathrm{C}$, according to the reaction $\mathrm{Na}_{2} \mathrm{CO}_{3}+\mathrm{nSiO}_{2} \rightarrow \mathrm{nSiO}_{2}$. $\mathrm{Na}_{2} \mathrm{O}+\mathrm{CO}_{2}$, where " $\mathrm{n}$ " can be a fractional number; b) dissolution in water of the "solid glass" obtained in the previous stage, in a reaction vessel, under high pressure and temperature - a sodium silicate solution and impurities (not reacted silica, for example) are produced in this stage; c) optional filtration, depending on the desired purity; d) evaporation of the water from the silicate solution for the production of solid sodium silicate. This process is considered expensive, due to the energy consumption with the fuel burning, to reach high temperatures of calcination, besides producing considerable air pollution by emissions such as dust, nitrogen and sulphur oxides ${ }^{1}$. Calcination also presents as disadvantage the need of maintaining the ovens due the possibility of attack in the refractory materials by sodium carbonate. Beyond this calcination process which is widely used in industrial scale, there is also a process based in the reaction of silica with aqueous sodium hydroxide $(\mathrm{NaOH})$ in autoclave, under high pressure and temperature, without calcination, as described in some patents ${ }^{2-6}$. In the the Rio Grande do Sul state (Brazil), the greater national rice producer, about 6,310 million tons of this rice were produced in harvest 2003/2004 ${ }^{7}$. Knowing that the hulls represent $20 \%$ of this value, the annual production of this residue is of the order of 1162000 tons. If all rice hull available in the state were burned for energy generation, the resultant production would of approximately 209000 ton ash per year (about $18 \%$ by weight of the hull). These ashes are rich in silica (about 90\%), making possible its use as raw material for obtaining several products of commercial interest ${ }^{8}$, such as silicon carbide ( $\mathrm{SiC})$, used as semiconductor, in the glass manufacture, in the portland cement production, as high strength ceramics and composites. This work has as objective to produce sodium silicate solution using RHA as silica source. The detailing of the production process is presented.

\section{Materials and Methods}

As silica source, it RHA from a local industry was used (Induber, Santa Maria, RS, Brazil). The received ashes were submitted to ball milling with a porcelain jar and microspheres of high alumina as grinding medium, and later passing through a 60 mesh sieve. By economic reasons, the ash was used as received, i.e., without being submitted to purifying process in order to increase silica content. Methods for obtaining pure silica from RHA can be found in the literature $^{9-12}$. Sodium hydroxide (Aldrich, purity $>99 \%$ ) was used as sodium source. The RHA was characterized by $\mathrm{X}$ ray diffraction (XRD), using a Shimadzu difratometer, with radiation $\mathrm{CuK} \alpha$, and by chemical analysis using spectrometry of atomic absorption (Equipment: Analytik JENA, model I vary 6, Germany).

Figure 1 presents the flow diagram for production of soluble sodium silicate.

The reaction between RHA and sodium hydroxide solution was carried through in two types of systems: open and closed. In the open system, the reaction was carried out under atmospheric pressure. The system consisted of a glass reaction vessel, heating source, temperature measuring device and reflux condenser, to keep constant volume of the reaction mixture. In the closed system, under pressure and temperature $\left(100-200{ }^{\circ} \mathrm{C}\right)$, the mixture of raw materials was placed in the interior of a $50 \mathrm{~cm}^{3}$ stainless steel autoclave coated internally with Teflon. The reaction step resulted in a sodium silicate solution and solid impurities, predominantly constituted of silica not reacted and water non-soluble residues. The sodium silicate solution was attained by a vacuum filtration system.

The conversion silica to silicate, expressed in weight percentage, was determined by mass balance, as described procedures to follow:

a) the solid residues obtained in the stage of filtration had been washed with distilled water and later dried at $110{ }^{\circ} \mathrm{C}$, for 24 hours. The conversion was determined from of known silica mass in the RHA and from the residue content gotten in the filtration. This conversion also can be calculated by procedures to follow; and 
b) from sodium silicate solution, a sample of known mass was overcome and was added sulfuric acid until it reaching $\mathrm{pH} 7.0^{13}$. In this $\mathrm{pH}$ the silica precipitates, also resulting a salt, the sodium sulfate $\left(\mathrm{N}_{\mathrm{a} 2} \mathrm{SO}_{4}\right)$. The removal of sodium sulfate was made using distilled water $\left(50{ }^{\circ} \mathrm{C}\right)$ by vacuum filtration. The process resultant silica gel was placed to dry at $110{ }^{\circ} \mathrm{C}$ for 24 hours, weighed and quantified for the determination of the silica content converted to silicate, in function of the amount of silica contained in the RHA;

To get a bigger trustworthiness in the result of the conversion, the procedures "a" and "b", previously described, had been both realized. Thus, the sum of the residues attained mass (procedure "a") and the silica mass gotten for procedure " $b$ " will have to be equal to the used ash mass in the reaction.

The following variables in this work had been analyzed: time of reaction (varying of 0 to 80 minutes), molar ratio $\mathrm{NaOH} / \mathrm{SiO}_{2}$ (1, 2, 3 and 4), molar ratio $\mathrm{H}_{2} \mathrm{O} / \mathrm{SiO}_{2}$ (11 and 22) and reaction temperature $\left(100,110,120,150\right.$ and $\left.200{ }^{\circ} \mathrm{C}\right)$. The time of " 0 hours" corresponds to the time necessary for reaction system to reach the desired temperature.

For the attainment of sodium silicate with molar ratio $\mathrm{H}_{2} \mathrm{O}$ / $\mathrm{SiO}_{2}=22$ and $\mathrm{NaOH} / \mathrm{SiO}_{2}=2$, for example, it was used $70 \mathrm{~g}$ of RHA, $80 \mathrm{~g}$ of $\mathrm{NaOH}$ and $396 \mathrm{~g}$ of distilled water.

\section{Results and Discussion}

The ash chemical composition was the following one (\% by weight): $94.4\left(\mathrm{SiO}_{2}\right), 0.61\left(\mathrm{Al}_{2} \mathrm{O}_{3}\right), 1.06\left(\mathrm{~K}_{2} \mathrm{O}\right), 0.77\left(\mathrm{Na}_{2} \mathrm{O}\right)$, $0.59(\mathrm{MnO}), 0.83(\mathrm{CaO}), 1.21(\mathrm{MgO}), 0.03\left(\mathrm{Fe}_{2} \mathrm{O}\right)$. It can be evidenced that the ash produced from the rice hull burning contains a great amount of silica and small amounts of other elements considered as impurities. The most common trace elements in RHA are sodium, potassium, calcium, magnesium, iron, copper, manganese and zinc ${ }^{14}$. Differences in composition may occur due to geographical factors, type of ground, year of harvest, sample preparation and analysis methods.

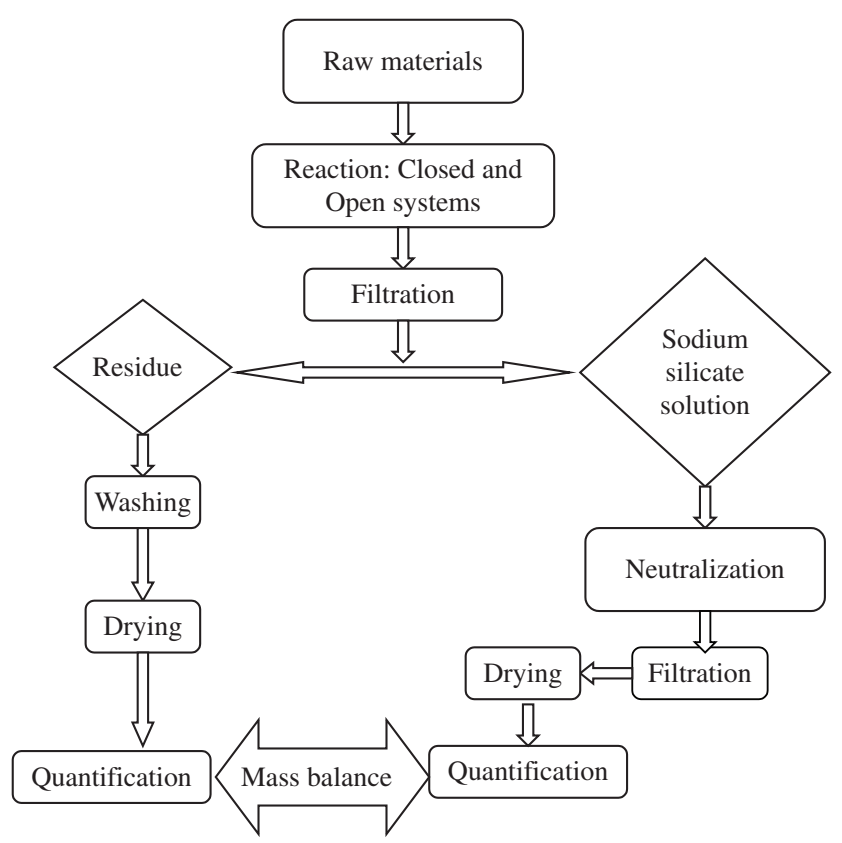

Figure 1. Flow diagram for production of soluble sodium silicate.
Figure 2 presents a sample of RHA, as received.

From Figure 2, it is observed that the ashes are black with gray particles as result of different steps of carbon combustion during the rice hull burning ${ }^{15}$. The burning of rice hull in air always leads to the formation of silica ash, which varies from the gray to black depending on inorganic impurities and unburned amounts ${ }^{16}$. Houston ${ }^{14}$ has classified RHA into high-carbon char, low-carbon gray ash, and carbon-free pink or white ash.

Figure 3 presents the influence of molar ratio $\mathrm{NaOH} / \mathrm{SiO}_{2}$ variation, for ratios of $\mathrm{H}_{2} \mathrm{O} / \mathrm{SiO}_{2}$ Equal to 11 and 22, on silica conversion into soluble silicate.

It is observed that the increase of the $\mathrm{H}_{2} \mathrm{O} / \mathrm{SiO}_{2}$ ratio from 11 to 22 practically does not modify the values of the conversion, for the different assayed $\mathrm{NaOH} / \mathrm{SiO}_{2}$ ratios. These tests had been also made in closed system at temperatures of 110 and $120^{\circ} \mathrm{C}$, with 1 hour of reaction, and was observed similar behavior for the conversion. Thus, for the following experiments, it was opted to using the $\mathrm{H}_{2} \mathrm{O} / \mathrm{SiO}_{2}$ ratio $=22$, due to the biggest easiness of filtration of the sodium silicate solution, since with lesser ratio (Equal to 11), forms a gelatinous solution of difficult filtration. It is also observed that the increase in the conversion is small with the rise of the $\mathrm{NaOH} / \mathrm{SiO}_{2}$ ratio. With this, for the following assays a $\mathrm{NaOH} / \mathrm{SiO}_{2}=2$ ratio was used, having thus a lesser consumption of $\mathrm{NaOH}$ in the syntheses.

Figure 4 presents the conversion results using the two types of reaction systems, for different reaction times.

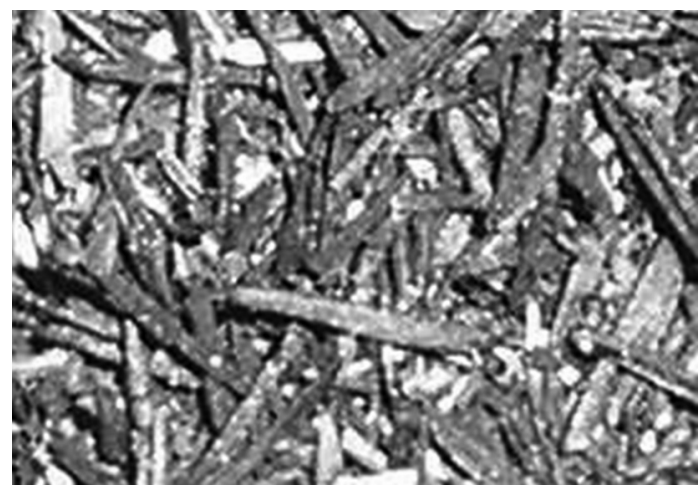

Figure 2. Macroscopy of RHA as received.

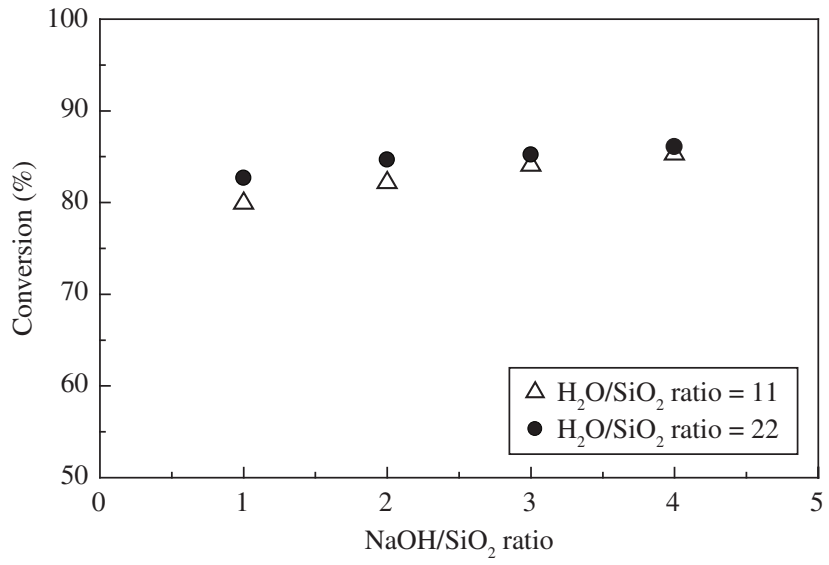

Figure 3. Silica conversion as function of $\mathrm{NaOH} / \mathrm{SiO}_{2}$ ratio, for $\mathrm{H}_{2} \mathrm{O} / \mathrm{SiO}_{2}$ ratios $=11$ and 22 (open system; 1 hour of reaction; $\left.\mathrm{T}=100{ }^{\circ} \mathrm{C}\right)$. 


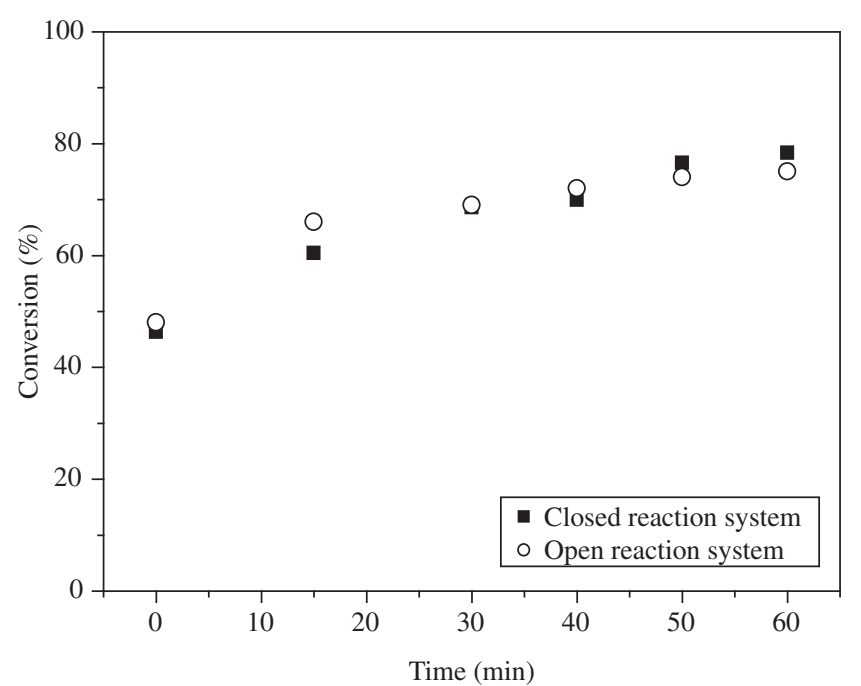

Figure 4. Silica conversion as function of reaction time, for the two types of systems: open and closed $\left(\mathrm{T}=100{ }^{\circ} \mathrm{C}, \mathrm{H}_{2} \mathrm{O} / \mathrm{SiO}_{2}\right.$ ratio $=22 ; \mathrm{NaOH} / \mathrm{SiO}_{2}$ ratio $=2$ ).

Figure 4 shows that the silica conversion into silicate presents a similar behavior for the two types of systems. In the time $t=0$, i.e., the time that the reaction system leads to reach the temperature of $100{ }^{\circ} \mathrm{C}$, already had the silicate formation, reaching $60 \%$ of conversion. With 60 minutes of reaction, time measured from the moment where the temperature of $100{ }^{\circ} \mathrm{C}$ was reached, a conversion of about $70 \%$ was attained for both the systems.

Figure 5 presents the influence of reaction temperature on silica conversion. It is observed that the conversion increases with the temperature rise, reaching $92 \%$ at $200{ }^{\circ} \mathrm{C}$, in only 20 minutes of reaction. In the biggest temperatures of reaction, the conversion reaches a constant value in lesser time. It is also observed that, at $200{ }^{\circ} \mathrm{C}$, exactly before the counting of reaction time, already the silicate has a great converted silica content, about $85 \%$.

The $\mathrm{X}$ rays diffractograms of the RHA and samples of residues (silica not dissolved + impurities) gotten in the aqueous sodium silicate filtration are presented in Figure 6. The RHA diffractogram indicates the presence of silica in the crystalline form due to the predominant presence of cristoballite $(2 \theta=21.9)^{17}$. The crystalline, amorphous silica or both presence is due directly to the temperature of burning or the method of ash attainment. When the burning temperature of the rice hull is high, the silica contained in the ash is predominantly crystalline. Shinohara and Kohyama ${ }^{17}$ had quantified the crystalline silica in leached ashes samples gotten by rice hull burning in some temperatures and times, and had observed that in temperatures around of $1000{ }^{\circ} \mathrm{C}$ it gets ash with predominant crystalline silica, getting $83 \%$ of crystalline silica at temperature of $1350{ }^{\circ} \mathrm{C}$; in the range of temperature of $450-700{ }^{\circ} \mathrm{C}$, the silica was presented under the amorphous phase (less than $5 \%$ of crystallinity).

The samples of residues analyzed for XRD had been those attained in the reactions at $100{ }^{\circ} \mathrm{C}$ and $200{ }^{\circ} \mathrm{C}$ in closed system, with 30 minutes of reaction and molar ratio $\mathrm{H}_{2} \mathrm{O} / \mathrm{SiO}_{2}=22$ and $\mathrm{NaOH} / \mathrm{SiO}_{2}=2$.

It is observed in the residue diffractogram at $100{ }^{\circ} \mathrm{C}$ the presence of sharp peaks, referring to the cristoballite and the quartz, indicating that a considerable amount of silica did not become silicate. In these conditions, in Figure 5, it is had about $70 \%$ of conversion, what it is equivalent $30 \%$ of silica not reacted. It also had the transformation of part of the cristoballite in quartz during the reaction. By the diffractogram of the $200{ }^{\circ} \mathrm{C}$ residue, is observed that the material is

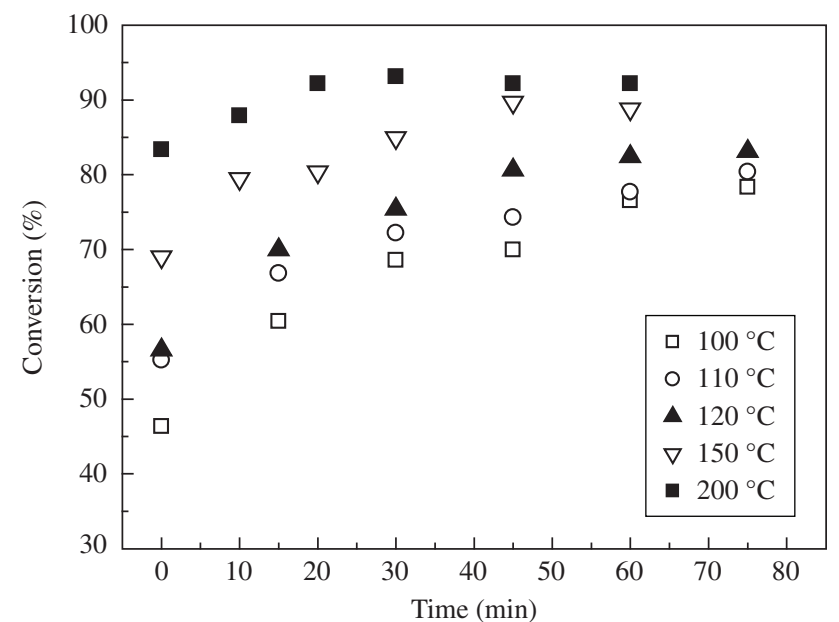

Figure 5. Silica conversion as function of reaction time for different temperatures $\left(\mathrm{H}_{2} \mathrm{O} / \mathrm{SiO}_{2}\right.$ molar ratio $=22 ; \mathrm{NaOH} / \mathrm{SiO}_{2}$ ratio $=2$; closed system $)$.

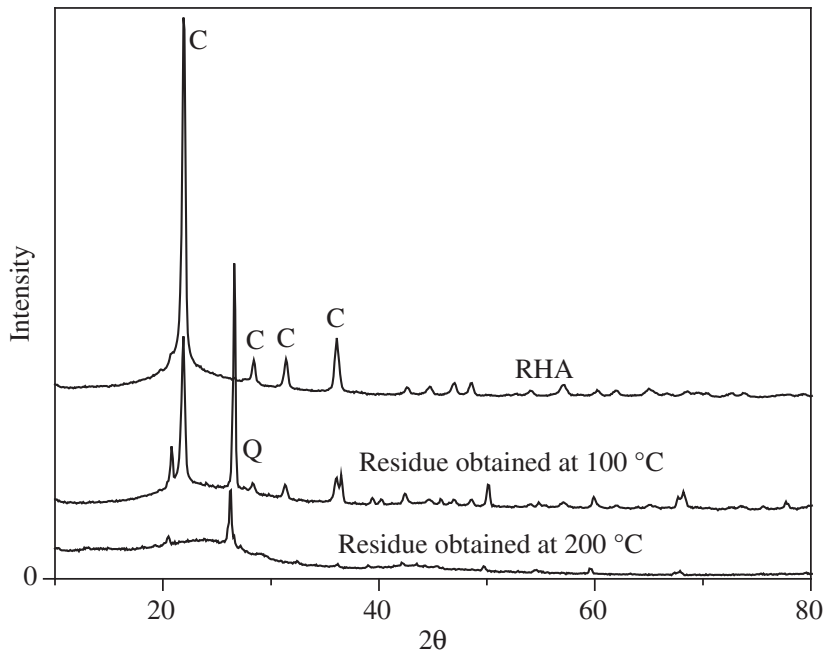

Figure 6. $\mathrm{X}$ rays diffraction of RHA and samples of residues attained in the filtration. $(\mathrm{C}=$ cristoballite; $\mathrm{Q}=$ quartz $)$.

practically amorphous, indicating that most of the present silica in the ash reacted forming sodium silicate, what corroborates the result presented in Figure 5, where it has a $92 \%$ conversion in 30 minutes of reaction.

\section{Conclusion}

It is possible to dissolve great part of the contained silica in leached ashes by the reaction with aqueous solution of $\mathrm{NaOH}$, in superior temperatures to $100{ }^{\circ} \mathrm{C}$; the dissolved silica percentage increases with the increase of the temperature and the time of reaction; the molar ratio $\mathrm{NaOH} / \mathrm{SiO}_{2}$ practically does not influence in the silica dissolution; the sodium silicate production using RHA as silica source can generate aggregate value to this residue.

\section{References}

1. Novotny R, Hoff A, Schuertz J. Process for hydrothermal production of sodium silicate solutions. United States Patent; 1991. nº 5,000,933. 
2. Haase R, Hunger V, Lenz A. Method of manufacturing aqueous solutions of alkali polysilicates. United States Patent; 1976. nº 3,984,526.

3. Deabriges J. Process for the manufacture of sodium silicate. United States Patent; 1982. $n^{\circ} 4,336,235$.

4. Metzger J, Lecouls H, Wojcik J. Process for producing solutions of alkali metal silicate in a static reactor. United States Patent; 1985. $\mathrm{n}^{\mathrm{o}} 4,520,001$.

5. Christophliemk P, Novotny R, von Laufenberg J. Hydrothermal production of clear sodium silicate solutions. United States Patent; 1988. $\mathrm{n}^{\circ} 4,770,866$.

6. Schimmel G, Kotzian M, Panter H, Tapper A. Process for producing amorphous sodium silicate. United States Patent; 1993. nº 5,229,095.

7. Riograndense Institute Of Rice. Available from: http://www.irga.rs.gov. br.

8. Foletto EL, Hoffmann R, Hoffmann RS, Portugal Jr. U.L., Jahn S.L. Aplicabilidade das Cinzas da Casca de Arroz. Química Nova. 2005; 25(6):1066-1060.

9. Real C, Alcala MD, Criado JM. Preparation of Silica from Rice Husks. J. Am. Ceram. Soc. 1996; 79(8):2012-2016.

10. Kalapathy U, Proctor A, Shultz J. A simple method for production of pure silica from rice hull ash. Biores. Technol. 2000; 73(3):257-262.

11. Yalçin N, Sevinç V. Studies on silica obtained from rice husk. Ceram. Int. 2001; 27(2):219-224.

12. Liou T-Horng. Preparation and characterization of nano-structured silica from rice husk. Mat. Sci. Eng. A. 2004; 364(1-2):313-323.

13. Kalapathy U, Proctor A, Shultz J. An improved method for production of silica from rice hull ash. Biores. Technol. 2002; 85(3):285-289.

14. Houston DF. Rice: chemistry and technology, ed. Am. Assoc. Cereal Chem., Inc., St. Paul, MN; 1972. p. 301.

15. Della VP, Kuhn I, Hotza D. Rice husk ash as an alternate source for active silica production. Materials Letters. 2002; 57(4):818-821.

16. Krishnarao RV, Subrahmanyam J, Kumar TJ. Studies on the formation of black particles in rice husk silica ash. J. Eur. Ceram. Soc. 2001; 21(1):99104.

17. Shinohara Y, Kohyama N. Quantitative analysis of tridymite and cristobalite crystallized in rice husk ash by heating. Ind. Health. 2004; 42(2):277285. 